Section Editor

Mitchell S.V. Elkind, MD, MS

\title{
Teaching NeuroImages: \\ Cortical blindness following acute obstructive hydrocephalus by a colloid cyst
}

Charles Champeaux, MD Athanasios Grivas, MD

Correspondence to Dr. Champeaux:

Charles.Champeaux@gmail.com

\section{Figure 1 Axial CT scan images without iodinated contrast media show enlarged occipital lobe}
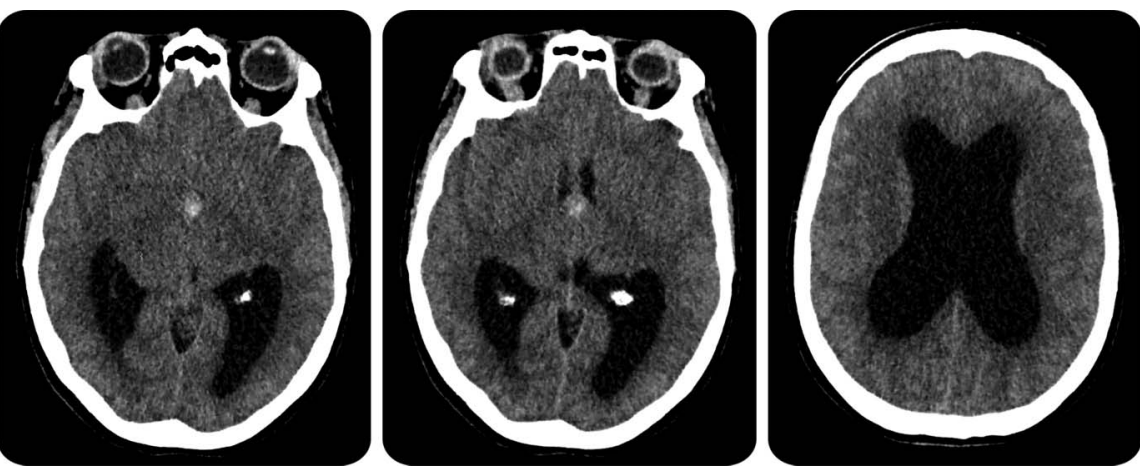

Horns of the lateral ventricles consistent with obstructive hydrocephalus secondary to the presence of a colloid cyst in the foramen of Monro.

A 46-year-old woman was admitted for acute headache, postseizure confusion, and visual loss. Urgent head CT scan showed obstructive hydrocephalus due to a colloid cyst (figure 1). External ventricular drains inserted emergently demonstrated CSF under pressure, above $40 \mathrm{~mm} \mathrm{H}_{2} \mathrm{O}$. MRI confirmed the suspected diagnosis of a colloid cyst and highlighted bilateral occipital lobe infarcts (figure 2). CT angiography showed no thrombosis of the posterior cerebral arteries (PCAs). After neurosurgical excision of the colloid cyst, the patient remained blind. The presumed mechanism of infarction was acute

\section{Figure $2 \quad$ MRI scan images}



(A) Sagittal T1 without gadolinium contrast injection shows a colloid cyst of $14 \mathrm{~mm}$. (B) Diffusion-weighted image depicts

Download teaching slides: Neurology.org

\section{restricted diffusion in both occipital lobes.}

From the Department of Neurosurgery, Institute of Neurosciences, Southern General Hospital, Glasgow, UK.

Go to Neurology.org for full disclosures. Funding information and disclosures deemed relevant by the authors, if any, are provided at the end of the article. 
compression of the PCAs against the edge of the tentorium cerebelli.

\section{AUTHOR CONTRIBUTIONS}

Charles Champeaux: drafting/revising the manuscript, accepts responsibility for conduct of research. Athanasios Grivas: acquisition of data and surgery.

\section{STUDY FUNDING}

No targeted funding reported.

\section{DISCLOSURE}

The authors report no disclosures relevant to the manuscript. Go to Neurology.org for full disclosures. 


\title{
Neurology
}

\author{
Teaching NeuroImages: Cortical blindness following acute obstructive hydrocephalus \\ by a colloid cyst \\ Charles Champeaux and Athanasios Grivas \\ Neurology 2015;84;e41-e42 \\ DOI 10.1212/WNL.0000000000001229
}

This information is current as of February 9, 2015

\section{Updated Information \& Services \\ Supplementary Material \\ Subspecialty Collections}

Permissions \& Licensing

Reprints including high resolution figures, can be found at:

http://n.neurology.org/content/84/6/e41.full

Supplementary material can be found at:

http://n.neurology.org/content/suppl/2015/02/07/WNL.0000000000001 229.DC1

This article, along with others on similar topics, appears in the following collection(s):

Clinical neurology examination

http://n.neurology.org/cgi/collection/clinical_neurology_examination

Hydrocephalus

http://n.neurology.org/cgi/collection/hydrocephalus

MRI

http://n.neurology.org/cgi/collection/mri

Stroke in young adults

http://n.neurology.org/cgi/collection/stroke_in_young_adults

Visual loss

http://n.neurology.org/cgi/collection/visual_loss

Information about reproducing this article in parts (figures,tables) or in its entirety can be found online at:

http://www.neurology.org/about/about_the_journal\#permissions

Information about ordering reprints can be found online:

http://n.neurology.org/subscribers/advertise

Neurology ${ }^{\circledR}$ is the official journal of the American Academy of Neurology. Published continuously since 1951, it is now a weekly with 48 issues per year. Copyright (C 2015 American Academy of Neurology. All rights reserved. Print ISSN: 0028-3878. Online ISSN: 1526-632X.



